\title{
Vitamin D Deficiency and its Repletion: A Review of Current Knowledge and Consensus Recommendations
}

\author{
Haroon $\mathrm{M}^{*}$ and Fitzgerald $\mathrm{O}$
}

Department of Rheumatology, St. Vincent's University Hospital, Ireland

\begin{abstract}
In last few years we have witnessed an explosion of research revealing the wide spread prevalence of vitamin $\mathrm{D}$ deficiency among all ages, communities, and different disease spectrums. Clearly, vitamin $\mathrm{D}$ has been shown to have effects beyond its traditional role in mineral metabolisms, which are mediated through the activation of vitamin $\mathrm{D}$ receptors distributed in a variety of tissues. There are strong epidemiological links between vitamin $\mathrm{D}$ deficiency and chronic diseases and will continue to be a focus of future research. However, this research information has not yet been fully translated into clinical practice. The increased awareness of the level of vitamin D deficiency in the general population and its potential impact on skeletal and extra skeletal health outcomes have highlighted the important need to understand and follow the latest research knowledge in this area. There remains a poor understanding among health professionals as regards the prescribing policy and the provision of appropriate vitamin $\mathrm{D}$ supplements. This review will discuss the physiological role of vitamin $\mathrm{D}$, and the available literature on vitamin $\mathrm{D}$ deficiency with respect to its definition, associated factors, prevalence, and management recommendations, and the safety of its repletion.
\end{abstract}

Key words: Vitamin D; Deficiency; Repletion

\section{Introduction}

Our knowledge regarding the physiological role of vitamin D has significantly advanced during last few decades. There have been strides in the development of strategies to prevent and treat the deficiency of this natural hormone - vitamin D; however, vitamin D deficiency remains under recognised and untreated. Vitamin D is a seco-steroid hormone with one endocrine function - calcium regulation- but with multiple autocrine functions. The principal function of vitamin $\mathrm{D}$ is to control calcium metabolism, and its deficiency impacts the quality and quantity of bone formation by affecting calcium absorption. Besides its effects on musculoskeletal system, 1,25-dihydroxyvitamin D inhibits cellular growth, stimulates insulin secretion, modulates immune function, and inhibits renin production. These findings most likely explain the observations that vitamin $\mathrm{D}$ deficient people are more prone to solid tumours, autoimmune diseases and hypertension [1]; however, discussing such health consequences is beyond the scope of this paper.

\section{Basic Physiology and Molecular Biology}

To understand the importance of vitamin $\mathrm{D}$, we need to understand its physiology. Vitamin D is a steroid hormone, and there are 2 forms of vitamin D - vitamin D2 (known as ergocalciferol) and vitamin D3 (named as cholecalciferol). Vitamin D2 is a plant extract and Vitamin D3 is synthesized by humans in the skin, when it is exposed to ultraviolet-B (UVB) rays from sunlight. Vitamin D is further hydoxylated in the liver to 25 hydroxyvitamin D (25OH vitamin D), which can accumulate in certain tissues. $25-\mathrm{OH}$ vitamin $\mathrm{D}$ is the predominant circulating form of vitamin $\mathrm{D}$ in the blood and because of its close regulation by the availability of vitamin $\mathrm{D}$, measurement of $25(\mathrm{OH})$ vitamin $\mathrm{D}$ is the most reliable indicator of vitamin $\mathrm{D}$ status. The active form, 1,25 dihydroxyvitamin $\mathrm{D}$, is formed by subsequent hydroxylation in the kidney, and its half-life is very short ( $<4$ hours). The renal hydroxylation is very closely regulated: enhanced by PTH, hypocalcaemia and hypophosphataemia and inhibited by $1,25(\mathrm{OH}) 2 \mathrm{D}$ itself [2]. 1,25(OH)2D is the principal hormonal form of vitamin $\mathrm{D}$, responsible for most of its biologic actions. Molecular mechanisms of action of 1,25-dihydroxyvitamin D include genomic and non-genomic effects [3]. Genomic effects of vitamin D are mediated by classical gene transcription or protein synthesis route, which is initiated by binding of $1,25(\mathrm{OH}) 2 \mathrm{D}$ to its nuclear high-affinity vitamin $\mathrm{D}$ receptor (VDR) [4,5], which results in changes in the gene transcription of mRNA and subsequent de novo protein synthesis [6]. However, non-genomic functions of vitamin D are generally rapid responses (minutes to hours). Many of these rapid responses are believed to be mediated by $1,25 \mathrm{D}$ binding to a plasma membrane-associated receptor [3,7], which in turn, initiates a cascade leading to the formation of a second messenger (cAMP, diacylglycerol, inositol triphosphate, arachidonic acid) or phosphorylation of intracellular proteins. Such receptors are located in classical target organs involved in vital calcemic actions of vitamin $\mathrm{D}$, such as the intestine, bone, kidney and parathyroid, as well as in many other tissues and cell types [2], including the immune system [8]. However, such non-genomic actions of vitamin D have not been demonstrated in vivo. The main biologic actions of $1,25-(\mathrm{OH})_{2}$ vitamin $\mathrm{D}$ are: absorption of calcium from intestine leading to the mineralization of bone matrix; osteoblast differentiation; and inhibition of parathyroid hormone secretion. In calcium deficiency states, $1,25(\mathrm{OH}) 2 \mathrm{D}$ mobilizes calcium stores from the bone through stimulation of monocytic cells to become mature osteoclasts, and thus, helps to maintain the serum calcium in the normal range [9]. Similarly, when vitamin D levels are low, compensatory secondary hyperparathyroidism increases the renal conversion of $25 \mathrm{OHD}$ and thereby maintains normal or slightly increased plasma levels of 1,25(OH)2D. Moreover, this active form of vitamin $\mathrm{D}$ is stored in the adipose tissue rather than remains in the circulation and, therefore, is not a good measure of vitamin D status

*Corresponding author: Dr. Muhammad Haroon, Department of Rheumatology, St Vincent's University Hospital, Elm Park, Dublin 4, Ireland, E-mail: mharoon301@hotmail.com

Received March 28, 2012; Accepted July 19, 2012; Published July 21, 2012

Citation: Haroon M, Fitzgerald O (2012) Vitamin D Deficiency and its Repletion: A Review of Current Knowledge and Consensus Recommendations. J Arthritis 1:105. doi:10.4172/2167-7921.1000105

Copyright: @ 2012 Haroon M, et al. This is an open-access article distributed unde the terms of the Creative Commons Attribution License, which permits unrestricted use, distribution, and reproduction in any medium, provided the original author and source are credited. 
in serum. Both 25OHD and 1,25(OH)2D undergo a 24-hydroxylation [10], which represents the first step in the biodegradation which ends with the formation of water-soluble calcitroic acid.

\section{Factors Associated With Vitamin D Deficiency}

\section{Poor intake}

There are multiple reasons for vitamin D deficiency. An important cause of vitamin $\mathrm{D}$ deficiency can be insufficient intake of dietary vitamin D. Extremely few foods naturally contain vitamin D, apart from oily fish in the form of salmon, mackerel, and sardines which are relatively rich in vitamin D3. Similarly, only a small number of foods are fortified with vitamin D such as milk, orange juice and some bread and cereals. Such fortification is used in many developed countries [11]. In Europe, margarine, vegetable oil and milk are commonly fortified, whereas in the USA, enrichment of flour, cornflakes, milk and juice is common practice. It is important to note here that $>90 \%$ of our vitamin $\mathrm{D}$ requirements come from sunlight exposure [12]. The average increment in serum $25(\mathrm{OH}) \mathrm{D}$ concentrations has been estimated at 1-2 nmol/L for every $40 \mathrm{IU}$ (1 microgram) of vitamin D3 depending on baseline $25(\mathrm{OH}) \mathrm{D}$ concentrations. Generally, the two forms of vitamin D, D2 (ergocalciferol) and D3 (cholecalciferol), are considered equivalent [13-15]. However, using $25(\mathrm{OH}) \mathrm{D}$ as an objective measure of response to vitamin D administration has shown that vitamin D3 is a more potent form of vitamin D compared to vitamin D2. Hence, some experts suggest that vitamin D2 should not be used for supplementation or fortification [16]. A recent systematic review examined the effects of food fortification on circulating $25(\mathrm{OH}) \mathrm{D}$ concentrations by reviewing 13 randomised controlled trials. This showed a consistently positive response of dietary vitamin D supplementation among young adults, postmenopausal women and elderly men [17]. There is also some suggestion that this treatment effect is dependent on baseline $25(\mathrm{OH})$ vitamin $\mathrm{D}$ levels, as the trials with low baseline $25(\mathrm{OH}) \mathrm{D}$ levels (i.e., $<50 \mathrm{nmol} / \mathrm{L}$ ) [18-21] have consistently demonstrated a greater percent increase in $25(\mathrm{OH}) \mathrm{D}$ levels at the end of study compared to trials with higher baseline 25(OH)D levels (i.e., $>50 \mathrm{nmol} / \mathrm{L}$ ) [22-25].

\section{Poor production, malabsorption and obesity}

Factors that can prevent exposure to sunlight are crucial in causing vitamin D deficiency. Such factors include: aging (which causes decreased dermal production through atrophic skin changes and decreased renal production of $1,25(\mathrm{OH})_{2}$ vitamin $\mathrm{D}$ by diminishing renal function), changes in latitude, time of the day, and life style factors, such as limited outdoor activity, can have a marked influence on the cutaneous production of vitamin D. Similarly, any hindrance to ultraviolet sunlight exposure onto the skin in the form of either sunscreen use or increased melanin pigmentation (dark skinned individuals) can potentially cause vitamin D deficiency. Vitamin D deficiency is also more common in adults who cover their skin for cultural reasons [26-29]. A systematic review found that the risk factors for vitamin D inadequacy most often found in post-menopausal women include poor sun exposure, limited time spent outdoors, inadequate dietary vitamin $\mathrm{D}$ intake, winter season and increased age [30]. Another important factor for vitamin $\mathrm{D}$ deficiency is poor absorption of vitamin $\mathrm{D}$, which generally occurs in people with fat malabsorption, given vitamin D is a fat-soluble vitamin. Such fat malabsorption is associated with a variety of medical conditions including some forms of liver disease, cystic fibrosis, and Crohn's disease.

Similarly, people who are obese or who have undergone gastric bypass surgery may become vitamin $\mathrm{D}$ deficient overtime given the greater amounts of vitamin $\mathrm{D}$ gets sequestered in the adipose tissue, and the part of the upper small intestine where vitamin D is absorbed is bypassed in such gastric surgery. Hence, people who are obese may need larger than usual intakes of vitamin $\mathrm{D}$ to achieve the required 25(OH)D levels comparable to those of normal weight [11].

\section{Minimal erythemal dose}

A minimal erythemal dose (MED) is the amount of sun exposure required to produce a faint pinkness to the skin [31-32]. Previous estimates suggest that a single MED of simulated sunlight will raise circulating levels of $25(\mathrm{OH}) \mathrm{D}$ comparable to the ingestion of 10,000 to 25,000 IU of vitamin D3 [33]. Thus, it is suggested that exposure of the face, arms, hands, and legs for $20 \%$ to $25 \%$ of that time (i.e., 6 to 8 minutes) 2 to 3 times a week is adequate to meet the body's requirement [34]. This time will vary depending on a number of external and individual factors such as latitude, season, time of day, amount of the clouds [35], age and especially the skin type, as people with dark skin require considerably longer (3-4 times) exposure time [36,37]. Hence, some believe that it is impractical to prescribe a uniform message to the general population given the number of variables that need to be taken into consideration [38].

\section{Season and latitude}

Seasonal and latitudinal variations of 25 hydroxyvitamin D levels have long been described, with the highest levels reported during summer sun exposure and decreased levels in late winter season [39]. The likely explanation is that during winter season, more ultra violet $\mathrm{B}$ photons are absorbed by ozone layer, due to the fact that sunrays enter at more oblique angle. It has been noted that above the latitude of $37^{\circ}$, there are even more marked decreases in the number of ultraviolet $B$ photons reaching the earth surface during the winter months of November to February. Therefore, very little vitamin D3 is produced in the skin during the winter [32]. Not surprisingly, Webb et al. have already shown that in the USA, ineffective vitamin D synthesis extended from October through March in Edmonton, where latitude is 52 degree north [40]. Similarly, in Boston $\left(42^{\circ} \mathrm{N}\right)$ no vitamin D is produced from November through February [34]. Between 0 and 10 degrees latitude, there is very intense sunlight for several hours before and after noon, year-round. People with pale or untanned skin will have plenty of exposure in just a few minutes. Between 10 and 30 degrees latitude, there are several hours of very strong sunlight each day, especially during the summer, but the hours after dawn and before dusk can be milder. Between 30 and 50 degrees latitude, sunlight can be strong during the summer only, and spring is generally mild. Upwards of 50 degrees latitude, inhabitants are particularly at risk given the summers are often short and they often have pale skin. Dark skin people living at these latitudes are at a very high risk of vitamin D deficiency.

A recent systematic review has evaluated the effect of UV exposure on serum $25(\mathrm{OH}) \mathrm{D}$ concentrations by reviewing 8 randomised controlled trials, where four trials used solar exposure and the other four used artificial UV-B sources. [41-48]. This has concluded that 25 $(\mathrm{OH}) \mathrm{D}$ levels increase with both solar and artificial UV-B exposure [17].

\section{The role of sunscreens}

It is important to recognize that sunscreens, while protecting from skin cancers, absorb the ultraviolet radiations before entering the skin and, hence, may block the most important source of vitamin D production leading to a theoretical risk of vitamin $\mathrm{D}$ deficient states. 
Sunscreens give different level of protection against sunburn, ranging from sun protection factor (SPF) of 6 to $>50$. Sunscreen controversy about vitamin $\mathrm{D}$ deficiency vs. the risk of skin cancer continues to persist. Earlier studies showed a significant drop in the cutaneous production of vitamin D with the use of sunscreens [49-51]. While, it has been shown that a sun protection factor of 8 can reduce the skin production of vitamin D by $95 \%$ (49), there are no randomized controlled trials to confirm the same. On the other hand, many trials, including a randomized controlled trial, have revealed that sunscreens do not prevent the production of sufficient vitamin D [43,52-56]. A recent review on this topic has concluded that although sunscreens can significantly reduce the production of vitamin $\mathrm{D}$, their normal usage does not generally result in vitamin D insufficiency [57]. Nonmelanoma skin cancers occur on the most sun exposed areas, such as the face and hands, whereas most melanomas occur on the areas least exposed to the sun [58]. Non-melanoma skin cancer is now the UK's commonest malignancy, and malignant melanoma is the commonest cancer in the 15-34 year group [59]. To add to the confusion, apart from the well known benefits of sun avoidance in reducing skin cancers, intermittent and occupational sun exposure has been found to reduce the risk of malignant melanoma $[60,61]$.

Too much sun is the main risk factor for skin cancer; on the other hand, too little sun and wearing sunscreen continuously may lead to vitamin D deficiency [32]. Hence, the health promotion message of emphasizing the importance of UV protection against skin cancers and the issue of low vitamin D due to sunlight avoidance should not be taken as opposing each other. We recommend the sensible exposure to sunlight, for example, a brief exposure to the sun before applying the sunblock.

\section{Infants}

Breast fed infants are among the many common groups which are considered at higher risk of developing vitamin D deficiency. Human milk generally provides $<25 \mathrm{IU} / \mathrm{L}$ to $78 \mathrm{IU} / \mathrm{L}$, which is not enough to meet vitamin D requirements $[62,63]$. Vitamin D content of breast milk is related to mother's vitamin D status; in other words, vitamin $\mathrm{D}$ deficiency in a pregnant woman causes deficiency in the fetus [63]. This can have direct impact on the baby's health, not only during their early life but also as an adult. For example, bone mineral accrual in early childhood and the risk of recurrent wheezing episodes in children have been linked to low vitamin $\mathrm{D}$ intake by women during pregnancy $[64,65]$. Maternal deficiency can cause tetany in neonates, which is caused by hypocalcemia and may accompany infantile or adult vitamin D deficiency. Tetany may cause paresthesias, carpopedal and facial spasm; and, if very severe, seizures. A recent report from Canada has shown that $94 \%$ of infants diagnosed with rickets had been breast fed [66]. Hence, American Association of Pediatrics recommends that infants, who are exclusively or partially breastfed, should be supplemented with $400 \mathrm{IU}$ of vitamin D per day [63].

\section{Issues in Defining Vitamin D Deficiency}

$25(\mathrm{OH})$ vitamin $\mathrm{D}$ is the major circulating form of vitamin $\mathrm{D}$. In clinical practice, measurement of $25(\mathrm{OH})$ vitamin $\mathrm{D}$ is used to diagnose intestinal malabsorption, vitamin $\mathrm{D}$ deficiency or intoxication, and to monitor therapeutic response in patients being treated for vitamin D-related disorders. Consensus has not been reached on exact cutoff points of $25(\mathrm{OH})$ vitamin $\mathrm{D}$ levels that can delineate vitamin $\mathrm{D}$ deficiency, but most studies and especially Institute of Medicine (IOM) agree on the following cut-offs: levels of $<20-25 \mathrm{nmol} / \mathrm{l}$ or $<12 \mathrm{ng} / \mathrm{ml}$ represent vitamin $\mathrm{D}$ deficiency that inevitably results in osteomalacia, if untreated; levels of $25-50 \mathrm{nmol} / \mathrm{l}$ or $12-20 \mathrm{ng} / \mathrm{ml}$ represent a milder form, often termed insufficiency, which can potentially lead to hyperparathyroidism, accelerated bone turnover and osteoporosis [78]. However, a growing number of researchers warn that the distinction between deficiency and insufficiency is artificial and there is much overlap between the two conditions. Studies have shown a significant improvement in calcium absorption at serum 25OHD level of 67.5 $\mathrm{nmol} / \mathrm{L}$ compared to $55.5 \mathrm{nmol} / \mathrm{L}$ [67]. Similarly, it has been observed that by increasing $25(\mathrm{OH})$ vitamin D levels from an average of 50 to $86 \mathrm{nmol} / \mathrm{L}$ increases calcium absorption by $45 \%$ to $65 \%$, implying that there is significant decrease in intestinal calcium absorption when the level is even $75 \mathrm{nmol} / \mathrm{L}$ or less [68]. In contrast to the findings of this study, dropping serum 25OHD from 122 to $74 \mathrm{nmol} / \mathrm{L}$ did not produce a significant difference in calcium absorption [69]. This suggests that vitamin $\mathrm{D}$ levels should ideally exceed $75 \mathrm{nmol} / \mathrm{L}$, and levels between 50 to $75 \mathrm{nmol} / \mathrm{L}$ can be considered relative insufficiency. As new data becomes available, the threshold for diagnosis of vitamin $\mathrm{D}$ deficiency is likely to rise even higher. Different values of $25(\mathrm{OH}) \mathrm{D}$ have been used as cut-offs to define low vitamin D states, and this depends on the distinct health outcome studied. The most commonly used functional measures to assess the adequacy of vitamin $\mathrm{D}$ status include: the level of $25(\mathrm{OH})$ vitamin $\mathrm{D}$ needed to maximally suppress the circulating parathyroid hormone; and the level associated with highest bone mineral density, greatest calcium absorption, reduced rates of bone loss, and reduced fracture rates. In this regard, for a long time the levels of $50 \mathrm{nmol} / \mathrm{L}$ were considered the cut-offs, given its association with suppression of parathyroid hormone [70]. However, the research has revealed few important facts: serum levels of 25-hydroxyvitamin D are directly related to bone mineral density, and maximum bone density is achieved when the 25 -hydroxyvitamin $\mathrm{D}$ level reached $100 \mathrm{nmol} / \mathrm{L}$ or more; when the level is $75 \mathrm{nmol} / \mathrm{L}$ or less, there is a significant decrease in intestinal calcium absorption; similarly, when the level is $50 \mathrm{nmol} / \mathrm{L}$, calcium absorption drops by $35 \%[68,71]$. This stimulates an interesting proposal that cut-offs should be based on determining an optimal level for health as opposed to the minimum level to prevent severe deficiency. Based on this concept, a number of world experts now believe that hypovitaminosis D (i.e. vitamin D 'deficiency') should be defined as a 25 -hydroxy $(25-\mathrm{OH})$ vitamin $\mathrm{D}$ level $\leq 75 \mathrm{nmol} / \mathrm{L}$ (i.e., $\leq 30 \mathrm{ng} / \mathrm{ml}$ in the U.S.) [72]. However, there are some experts who believe this may be too low and they believe the vitamin $\mathrm{D}$ sufficiency should be defined as a plasma $25(\mathrm{OH}) \mathrm{D}$ concentration of $>80 \mathrm{nmol} / \mathrm{L}$ [73] and $>100$ $\mathrm{nmol} / \mathrm{L}$ [74]. Interestingly, IOM adopts a much conservative approach in defining vitamin D deficiency - serum $25(\mathrm{OH}) \mathrm{D}$ was considered as adequate at a level of $20 \mathrm{ng} / \mathrm{ml}$. This report has been discussed in detail somewhere else in this paper.

One major issue contributing to heterogeneous results and limiting the pooling of data is the actual method of measurement of vitamin $\mathrm{D}$, where considerable variability exists. Among the several methods available are the ones based on competitive protein binding assay (CPBA), radioimmunoassay (RIA), enzyme-linked immunoassay, random access automated assay using chemiluminescence technology, high performance liquid chromatography (HPLC) and liquid chromatography-mass spectrometry (LC-MS) [75]. These methods have been shown to give discordant results [76]. For example, the chemiluminescent assay usually provides higher $25(\mathrm{OH})$ vitamin D results compared to other methodologies. In addition, some can underestimate the total $25(\mathrm{OH}) \mathrm{D}$ due to their inabilities in individually quantifying ergocalciferol $[25(\mathrm{OH}) \mathrm{D} 2]$ and cholecalciferol $[25(\mathrm{OH})$ D3] [77]. To overcome these issues, a standard reference preparations 
were long awaited so that serum $25(\mathrm{OH}) \mathrm{D}$ can be accurately and reliably measured, and validated. In July 2009, a standard reference material has been produced by the National Institute of Standards and Technology (NIST), in collaboration with the National Institutes of Health's Office of Dietary Supplements, and this is hoped to improve the standardisation of operating procedures and reference intervals $[78,79]$.

\section{Prevalence of Vitamin D Deficiency}

The prevalence of vitamin D deficiency is very well documented across the globe, and no age, race or the disease spectrum seem to be free of this deficiency. The majority of such studies are focussed on high-risk patients, for example, elderly patients living in institutions, children and young adults, and pregnant females. People in the younger age groups, who are otherwise healthy, are assumed not to require a dietary source of vitamin $\mathrm{D}$. There is accumulating evidence of the high prevalence of vitamin D deficiency in healthy young adults. Among rheumatology outpatient attendees (the patient's ages ranged from 19-91 years of age, the mean age was $53 \pm 16$ years), a recent study has shown that the age of patients did not substantially influence the prevalence of vitamin D deficiency, as $78 \%$ of patients who were aged $\leq 30$ years were low in vitamin D [80]. A UK study, which was carried out in similar rheumatology outpatient settings, has shown that vitamin $\mathrm{D}$ deficiency is significantly more prevalent amongst general rheumatology outpatients than osteoporotic or osteopaenic patients, irrespective of whether they were receiving vitamin D supplementation at the time of measurement [81]. Cystic fibrosis patients are well known to suffer from low vitamin D levels due to poor absorption of fat-soluble vitamins, and accordingly there are recommendations of its routine monitoring and supplementations in such patients [8284]. Research has shown that the level of vitamin D deficiency and secondary hyperparathyroidism among general rheumatology patients is comparable to the patients suffering from cystic fibrosis ( $87 \%$ vs. $90 \%$ patients had vitamin D levels $<30 \mathrm{ng} / \mathrm{ml}$ and $21 \%$ vs. $25 \%$ patients had secondary hyperparathyroidism, respectively [80]. This makes one to suggest that rheumatology patients are at a higher risk of suffering from vitamin D deficiency; however, more research is needed to prove this hypothesis

The likely explanation for vitamin D deficiency in young adults is the low consumption of vitamin D containing foods, lack of exposure to sunlight and limited outdoor activities. The fact that there are very few foods, which are fortified with vitamin D in Europe, complicates this issue. The problem is not confined to the residents of temperate climates; there are also reports of a high prevalence of low vitamin D status among people living in Qatar, Middle East, India, Pakistan, and Ethiopia [85-89]. Moreover, it is alarming to note that in recent years, a resurgence of rickets has been observed among ethnic and cultural minority groups in the United Kingdom, Netherlands, Denmark and in Australasia [90-97]. Similarly, another report, where 25-hydroxyvitamin D were assessed in 8532 European postmenopausal women with osteoporosis or osteopenia, has shown a high prevalence of vitamin D inadequacy in European postmeno $\neg$ pausal women $(79.6 \%$ and $32.1 \%$ when considering cut-offs of 80 and $50 \mathrm{nmol} / \mathrm{L}$, respectively) [98]. Among HIV-infected patients, a recent study has reported a high prevalence of low vitamin D levels (70\%). It has also been observed that some HIV therapies effect vitamin D metabolism and contribute to its deficiency [99]. Very low levels of vitamin D have been described in critically ill patients. Australian researchers have noted that almost half of people in an intensive care unit (ICU) were deficient in vitamin $\mathrm{D}$, with the lowest levels of vitamin $\mathrm{D}$ noted among those who were the sickest or who died during their ICU stay [100]. Similarly, very low levels of vitamin $\mathrm{D}$ are reported in almost all different clinical settings, for example, in outpatient clinics, inpatients, and also in primary care settings [101-107]. Clearly, the risk of developing vitamin D deficiency extends well beyond the traditional risk categories of nursing home or older housebound residents.

\section{Treatment of Vitamin D Deficiency}

Natural foods are very poor reservoirs of vitamin D, and their fortification is generally not sufficient. The treatment options to achieve optimal circulating level of $25(\mathrm{OH}) \mathrm{D}$ are sunlight, artificial ultraviolet light and vitamin D supplementation.

\section{Vitamin D3 vs. Vitamin D2}

Vitamin D is available in two different formulations: vitamin D2, better known as ergocalciferol; and Vitamin D 3, also called cholecalciferol. Most experts believe that vitamin D3 is more efficacious than vitamin D2 in raising serum 25(OH) vitamin D levels. Rather, the differential efficacy of vitamin D2 and D3 in the treatment of rickets has been reported since 1930 [108]. There are a multitude of reasons to explain this. For example, vitamin D2 has a shorter half life and an increased rate of clearance from the circulation. There is possibly a higher affinity of hepatic 25-hydroxylase for vitaminD3 than for vitamin D2 [109], and 1,24(OH) D2 has less affinity for vitamin D receptor than does $1,24(\mathrm{OH}) 2 \mathrm{D} 3$ [110]. This has been confirmed in birds, monkeys and rats [111-113]. In humans, vitamin D3 supplementation has been shown to raise $25(\mathrm{OH})$ vitamin D levels more than vitamin D2 supplementation. Using equal molar doses of vitamin D2 and D3, a study has shown a much greater increase of $25(\mathrm{OH}) \mathrm{D}$ levels with vitamin D3 [114]. Similarly another study reported that to obtain the same effect, the dose of vitamin D2 was 2.5 times the dose of vitamin D3 [115]. In another study, a single dose of 50,000 IU of vitamin D2 or D3 revealed that serum 25(OH)D returned to baseline levels by day 14 with vitamin D2; however, with vitamin D3, the serum 25(OH)D levels peaked at day 14 and remained above the baseline levels up to day 28 [116]. In intervention trials, the average increment in serum $25(\mathrm{OH})$ $\mathrm{D}$ has been estimated at $1.2 \mathrm{nmol} / \mathrm{l}$ for every mcg (40 IU) of vitamin D3 [117], and a much smaller increment of only $0.3 \mathrm{nmol} / \mathrm{L}$ for every microgram of vitamin D2 supplementation [118]. Another very recent trial, using vitamin D doses of 50,000 IU/week for 12 weeks, has revealed that $\mathrm{D} 3$ was not only about $87 \%$ more potent in raising and maintaining serum $25(\mathrm{OH}) \mathrm{D}$ concentrations, but also produced 2- to 3 -fold greater storage of vitamin D than does equal doses of D2 [119]. Conversely, it has been shown in some studies that vitamin D2 and vitamin D3 are equally effective in humans to raise circulating $25(\mathrm{OH}) \mathrm{D}$ levels [120122]. We believe that vitamin D3 is a more potent form of vitamin $D$ compared to vitamin D2, and should preferable be used. However, it is important to emphasise that the increase in serum vitamin $\mathrm{D}$ levels is inversely related to the starting level of $25(\mathrm{OH}) \mathrm{D}$ [123].

\section{Available guidelines}

There are a number of recommendations from different clinical organisations for addressing the epidemic of vitamin D deficiency. These clinical practice guidelines are based on expert opinions and a review of the available evidence.

- A position statement from the working group of the Australian and New Zealand Bone and Mineral Society, Endocrine Society of Australia and Osteoporosis Australia outline the people at risk of developing 
vitamin $\mathrm{D}$ deficiency, and the recommendations for managing vitamin $\mathrm{D}$ deficiency [124]. This states that a significant number of people residing in Australia are deficient in vitamin D. The general population should ensure the exposure of hands, face and arms to one-third of a minimal erythemal dose of sunlight, or should take vitamin D supplement of $400 \mathrm{IU} /$ day. Patients with vitamin D deficiency should take supplementation of 3000-5000 IU ergocalciferol per day for 6-12 weeks, and in those with moderate to severe deficiency, larger-dose preparations of vitamin $\mathrm{D}$ should be considered.

- An international public health project was initiated and named as Daction in an attempt to better address vitamin D deficiency [125]. This particularly emphasises the importance of maintaining vitamin $\mathrm{D}$ levels at $100-150 \mathrm{nmol} / \mathrm{L}$, and this was considered as safe.

- In 2007, the Canadian cancer society announced recommendations of vitamin D supplementations, based on the mounting evidence linking vitamin D to reduced risk of different cancers [126]. It was suggested that during the autumn and the winter, all adult Canadians should consider taking $1000 \mathrm{IU} /$ day of vitamin D, however, people at highrisk of developing vitamin D deficiency should consider supplementing $1000 \mathrm{IU} /$ day of vitamin D throughout the year.

We believe that a word of caution is needed, given the lack of welldesigned randomised-controlled trials to prove or disprove the notion of a causal role of vitamin D in cancer prevention. However, since there is very low risk of harm in enhancing vitamin D levels, we strongly support the need for vitamin D repletion

- Guidelines from Poland also recommend that those adults with inadequate sun exposure or those aged $>65$ years, require a minimum supplementation of 800-1000 IU/day of vitamin D [127].

- A round table discussion at the 5th International Symposium on the Nutritional Aspects of Osteoporosis was held in 2003, and the consensus among the experts was that a daily intake of $600 \mathrm{IU}$ of vitamin $\mathrm{D}$ is required to reach a mean serum $25(\mathrm{OH}) \mathrm{D}$ level of $50 \mathrm{nmol} / \mathrm{l}$, and an intake of at least $800-1,000 \mathrm{IU}$ is needed to attain a mean level of 75 $\mathrm{nmol} / \mathrm{l}$. Moreover, it was suggested that a level between $50-80 \mathrm{nmol} / \mathrm{L}$ is required for optimal bone health, with a consensus median threshold of $75 \mathrm{nmol} / \mathrm{L}$ [128]

- International Osteoporosis Foundation (IOF) published its position statement on optimal vitamin D status in early 2010 [129]. These guidelines were specifically designed for elderly women and men aged over the age of 60 to 65 years, since most of the available evidence is based on this particular subset of population. These recommendations are:

- The dose of vitamin $\mathrm{D}$ required for optimal vitamin $\mathrm{D}$ status depends on an individual's baseline level of $25(\mathrm{OH}) \mathrm{D}$, their BMI, and their level of sun exposure.

- For fall and fracture prevention, a serum 25(OH) D threshold of $75 \mathrm{nmol} / \mathrm{L}$ is considered optimal.

- Serum 25(OH)D increases by about $1 \mathrm{ng} / \mathrm{mL}$ (2.5 nmol/L) for every $100 \mathrm{IU}$ of additional vitamin D each day

- The estimated average vitamin $\mathrm{D}$ requirement to acquire the serum level of $75 \mathrm{nmol} / \mathrm{L}$ is 800 to $1,000 \mathrm{IU}$ per day. This might need to be adjusted depending on the associated risk factors, such as, the starting level of $25(\mathrm{OH}) \mathrm{D}$, obesity, associated osteoporosis, poor sun exposure, malabsorption and residents or immigrants from South Asia and Middle East.

- To measure serum vitamin D levels for such at risk populations, as this not only helps to estimate the repletion dose, but also serves as a baseline for future retesting.

- Osteoporosis Canada published its guidelines statement in
September 2010 [130], and supported recommendations aiming for serum 25-hydroxyvitamin $\mathrm{D}$ levels above $75 \mathrm{nmol} / \mathrm{L}$. These recommendations were directed for general population and not confined to osteoporotic population. Vitamin D supplementation was considered indicated given that most Canadian adults have insufficient exposure to sunlight and dietary intake to maintain this level throughout the year. Recommended intake for low-risk and younger adults was suggested at 400-1000 IU daily and for high-risk and older adults, to $800-2000$ IU daily.

- In late 2010, new Canadian guidelines for the management of osteoporosis were published, which recommend higher intakes, with routine supplementation at 400 to $1000 \mathrm{IU}$ daily for those at low risk and up to 2000 IU daily for high-risk individuals [131]. It is important to note here that such higher intake of vitamin D are suggested for osteoporotic patients only.

- In November 2010, Institute of Medicine (IOM) updated their original 1997 set of recommendations. They concluded that the majority of Americans and Canadians are receiving adequate amounts of both calcium and vita $\neg$ min $\mathrm{D}$, and also warned regarding the toxicity of vitamin D with bigger doses [78]. Although, they reviewed a range of health outcome measures, inconclusive and unreliable evidence of vitamin D and calcium supplementation was noted in all of these outcomes, apart from its role in bone health. Therefore, these recommendations are based on the role of vitamin $\mathrm{D}$ and calcium in bone health only. These recommendations suggest: the adequate level of serum $25(\mathrm{OH}) \mathrm{D}$ is $45 \mathrm{nmol} / \mathrm{L}(20 \mathrm{ng} / \mathrm{ml})$, with a range of $45-75$ $\mathrm{nmol} / \mathrm{L}(20-50 \mathrm{ng} / \mathrm{ml})$; there is no improvement in bone growth and maintenance with vitamin $D$ levels above $75 \mathrm{nmol} / \mathrm{L}(50 \mathrm{ng} / \mathrm{ml})$; the upper limit of daily intake is now doubled to 4,000 IU of D3 per day; and recommended dietary allowance (RDA) has been set at $600 \mathrm{IU} /$ day for everyone apart from those aged $>70$ years of age, where RDA was suggested to be at $800 \mathrm{IU} /$ day. It should be emphasised that IOM was given the task of assessing the current data on health outcomes associated with calcium and vitamin $\mathrm{D}$, and to update dietary reference intakes. Hence, this IOM report is a guide to food manufactures, and it was not the mission of that report to offer medical guidance for physicians, rather this should be left to the various societies issuing their own medical recommendations. These recommendations have been controversial [132], but one good outcome is the undoubted recognition of the key role of calcium and vitamin D in skeletal health, consistent with a cause-and-effect relationship. Hence, rheumatologists should routinely consider identifying and treating this extremely common condition - low vitamin D state - which has got excellent potential for both prevention and treatment.

\section{Effects of intermittent high-dose of vitamin $D$ regimens}

It is also important to discuss recent concerns regarding very high doses of vitamin D regimens. A double blind placebo-controlled trial has shown that a single annual 500000 -IU oral dose of cholecalciferol (vitamin D3) increased risk of falls and fractures, with the greatest increase occurring during the first 3 months after dosing [133]. Similarly, another randomized, double-blind, placebo-controlled trial has evaluated the efficacy of annual 300,000 IU intramuscular vitamin D2 (ergocalciferol) injection over 3 years. This particular study has reported that annual high doses of vitamin D were ineffective in preventing non-vertebral fractures [134]. It seems that rather than very high doses of intermittent vitamin $\mathrm{D}$ replacements, more frequent lower-doses regimens should be opted. Clearly, further research is needed to better understand these findings. 


\section{Controversy over Calcium and Vitamin D: Calcium or No Calcium}

An acceptable threshold for calcium intake has not been defined so far. Most studies have used a daily calcium dose of 1,000-1,200 mg [135138]. There had been some controversy as regards the additional benefit of adding calcium to vitamin $\mathrm{D}$ for fracture prevention. The arguments against achieving any significant benefit of adding calcium to vitamin D comes from two studies, which showed that non-vertebral fracture prevention is calcium-independent provided the vitamin $\mathrm{D}$ dose is greater than $400 \mathrm{IU}$ per day $[139,140]$. Moreover, a 2007 meta-analysis has revealed that calcium supplementation, whether in lower or higher doses, had no effect on hip fracture risk reduction [141]. Likewise, a 2009 meta-analysis revealed no additional benefit of adding calcium therapy to higher doses of vitamin D supplementation (482-770 IU/ day) for non-vertebral fracture risk reduction [142]. On the contrary, Tang et al. has shown in 2007, through an extensive meta-analysis, that combination of calcium and vitamin D is more effective than calcium or vitamin D alone. More importantly, it showed that most papers reporting a negative effect of the calcium-vitamin $\mathrm{D}$ association were linked to a poor adherence to treatment [143], and minimum doses of $1200 \mathrm{mg}$ of calcium and $800 \mathrm{IU}$ of vitamin D were recommended for best therapeutic effect.

Similarly, three recent systematic reviews, including a Cochrane review, have concluded that vitamin $\mathrm{D}$ supplementation without additional calcium intake was ineffective in preventing fractures [144146]. A consensus statement from leading osteoporosis societies has suggested the combination of vitamin $\mathrm{D}$ with calcium, both for their better efficacy and, perhaps, for optimising adherence [147]

Extraskeletal adverse events of calcium intake are quite complicated. Recent meta-analysis of randomised placebo controlled trials showed that calcium supplementation at doses of $\geq 500 \mathrm{mg} /$ day without additional vitamin D was associated with a $30 \%$ increase in the incidence of myocardial infarction and an insignificant increase in the risk of stroke and mortality [148]. Similarly, a 2008 randomised controlled trial of $1,000 \mathrm{mg} /$ day of calcium revealed a $47 \%$ increase in relative risk of combined cardiovascular endpoints [149]. Furthermore, the association of calcium intake with renal stones is well established. A randomized controlled trial in 36,282 postmenopausal women reported that a combination of supplemental calcium $(1,000 \mathrm{mg} /$ day) and vitamin D (400 IU/day) was associated with a $17 \%$ increase in the incidence of renal stones or renal insufficiency [138]. On the contrary, a recent analysis of calcium supplementation and the risk of atherosclerotic vascular disease in older women has shown calcium supplementation of $1200 \mathrm{mg}$ daily does not significantly increase the risk of atherosclerotic vascular disease in elderly women. This analysis was based on the results of a 5-year randomized controlled trial with a further 4.5-year follow-up observation [150]. Similarly, long-term follow up of RECORD study patients has shown that daily vitamin D or calcium supplementation did not affect vascular disease mortality [151]. Studies to date do not permit definitive conclusions since no randomised controlled trials have been conducted primarily to assess the effect of calcium supplementation on vascular events. Rather the information is based on secondary analysis and reviewing the unpublished data on cardiovascular events from the previous studies. Due to these concerns, it seems reasonable to recommend supplementing vitamin $\mathrm{D}$ and calcium only to those who are at increased risk of osteoporosis, and very reassuringly, calcium and vitamin $\mathrm{D}$ supplementation does not influence coronary or cerebrovascular risk in generally healthy postmenopausal women $[146,152]$. We recommend that at the very least all post-menopausal women and men over 65 years take daily calcium supplementation of $1200 \mathrm{mg} /$ day, and it is imperative to assess dietary calcium consumption and adjust the total calcium intake accordingly. . This is worth highlighting that presumed normal range of calcium levels differ in many countries, and it is vital to use reference local population otherwise, there is a potential risk of labelling erroneously hypercalcaemia/hypocalcaemia. Clearly, further work needs to be done.

\section{Safety of Repleting Vitamin D Stores}

Vitamin $\mathrm{D}$ therapy is generally considered safe in most individuals. There is no evidence of adverse effects with serum $25(\mathrm{OH}) \mathrm{D} \leq 70$ $\mathrm{ng} / \mathrm{ml}$, i.e. $175 \mathrm{nmol} / \mathrm{L}$. In addition, published reports of vitamin D toxicity have nearly all involved intake $\geq 40,000-50,000$ IU per day for prolonged period of times [153]. It has been shown that healthy humans produce about 4,000 units of vitamin $\mathrm{D}$ a day, from all sources [154]. Moreover, studies using 10,000 IU of vitamin D/day for up to 5 months did not cause toxicity [155]. Currently, the upper tolerable level for vitamin D supplementation is 2,000 IU/day for both males and females ( 1 year and older) including pregnant and nursing females, and $1,000 \mathrm{IU}$ for infants (0-12 months). Some experts raise the upper limit of vitamin D supplementation to $10,000 \mathrm{IU}$ as per many safety trials [156]. The issue of toxicity was especially highlighted when accidental overfortification of milk from 1985 to 1991 led to a suspected outbreak of hypervitaminosis D associated with severe illness and death in the USA [157]. It is unfortunate that most trials have excluded subjects with renal insufficiency or hypercalcemia, and included short durations of exposure to vitamin D. The WHI trial was the largest trial (seven years follow up of 36,282 subjects) showing a significant increase in kidney stones among postmenopausal women taking only $400 \mathrm{IU}$ vitamin D3 plus calcium $1,000 \mathrm{mg}$ a day [138]. However, it is difficult to make firm conclusions from this study due to the following: documentation was made of only patient reported renal stones rather than the review of medical records or confirmed by physicians, and very poor compliance rate of only $50-55 \%$. A systematic review has found inadequate reporting quality of vitamin $\mathrm{D}$ toxicity and inadequate power to detect adverse events in most of the reported trials; however, good tolerability of vitamin D supplementation above current reference intakes was observed [17].

One plausible explanation for vitamin $\mathrm{D}$ toxicity is the combination of heavy sun exposure with excessive supplementation of vitamin D. There are a number of contraindications to vitamin D therapy. Hypersensitivity to vitamin D can occur, and primary hyperparathyroidism is the most common example where vitamin D may exaggerate hypercalcemia. Occasionally, hypercalcemia due to vitamin $\mathrm{D}$ therapy can occur when large groups of elderly people are given vitamin D supplements, but this is likely due to the fact that vitamin D deficiency can mask primary hyperparathyroidism in this group. In addition, patients with chronic granulomatous diseases, such as sarcoidosis, tuberculosis and lymphoma can become hypercalcemic with vitamin $\mathrm{D}$ supplementation as there is additional production of 1,25-dihydroxyvitamin $\mathrm{D}$ from macrophages [158,159]. These conditions are preferably labelled as "vitamin D hypersensitivity syndromes".

Vitamin D toxicity remains undetected for a considerable period of time, and usually presents initially with elevated urine calcium excretion and later on, an elevated serum calcium levels. Early symptoms of hypercalcemia may include nausea, vomiting, and anorexia, followed by polyuria, polydipsia, weakness, fatigue, somnolence, headache, dry mouth, metallic taste, vertigo, tinnitus, and ataxia. Renal impairment and metastatic calcifications may occur, particularly affecting the kidneys. Elevated serum calcium levels are a constant finding when toxic symptoms occur. Serum 25(OH)D levels are usually elevated $>150 \mathrm{ng} / \mathrm{mL}(>375 \mathrm{nmol} / \mathrm{L})$. For the diagnosis of vitamin $\mathrm{D}$ toxicity, levels of $1,25(\mathrm{OH}) 2 \mathrm{D}$ need not to be measured, as they may be normal. 
Treatment consists of stopping vitamin $\mathrm{D}$, restricting dietary calcium, restoring intravascular volume deficits, and, if toxicity is severe, giving corticosteroids or bisphosphonates. However, it is quite reassuring that toxicity stemming from pharmacological doses of vitamin $\mathrm{D}$ is very uncommon, and majority of such reports of toxicities are caused by accidental overdose. Vigilance is imperative as the response to vitamin $\mathrm{D}$ supplementation or sun exposure widely varies; however, there are no consensus regarding how to best monitor those using regular supplementations.

\section{Conclusion}

In summary, vitamin $\mathrm{D}$ deficiency is now well recognised as a growing health concern. There is enough evidence to support its role in bone health; however, there is insufficient evidence to prove its role beyond musculoskeletal health. Given the extreme rarity of vitamin D toxicity, it seems reasonable to advise general public (at the very least in all post-menopausal women and men $>65$ years of age) regarding the use of such foods, which contain higher contents of vitamin $\mathrm{D}$, or to use fortified food products. A clear public health strategy and guidance on vitamin $\mathrm{D}$ supplementation is warranted. We hope that with growing interest and research in the role of vitamin $\mathrm{D}$, effective management strategies will emerge. .

\section{Future Perspective}

Firstly, standardization of vitamin D deficiency and repletion protocols are required to better frame future studies of vitamin D supplementation. Secondly, studies should also aim for genotype scoring in addition to the common risk factors for prediction of various health outcomes; in other words to look for most "at-risk" genotype. Thirdly, while a wealth of epidemiological studies support the importance of vitamin $\mathrm{D}$ beyond bone health, further trials in the form of well-designed randomised-controlled trials are required before claims can be made about the role of vitamin $\mathrm{D}$ in the prevention of chronic diseases.

\section{Summary}

- Vitamin D deficiency remains under recognised and untreated

- Vitamin D2 is a plant extract and Vitamin D3 is synthesized by humans in the skin, when it is exposed to ultraviolet-B (UVB) rays from sunlight

- 25-OH vitamin D is the predominant circulating form of vitamin $\mathrm{D}$ in the blood and because of its close regulation by the availability of vitamin $\mathrm{D}$, measurement of $25(\mathrm{OH})$ vitamin $\mathrm{D}$ is the most reliable indicator of vitamin $\mathrm{D}$ status

- In vitro studies have shown that molecular mechanisms of action of 1,25-dihydroxyvitamin D include genomic and non-genomic effects. Genomic effects of vitamin D are mediated by classical gene transcription or protein synthesis route, and non-genomic effects are mediated by the formation second messengers

- Common factors associated with vitamin D deficiency include poor intake, malabsorption, obesity, season and latitude, sunscreens, increased skin pigmentation, age and especially the skin type

- Consensus has not been reached on exact cut-off points of 25 $(\mathrm{OH})$ vitamin $\mathrm{D}$ levels that can delineate vitamin $\mathrm{D}$ deficiency, but most studies agree that levels of $<20-25 \mathrm{nmol} / \mathrm{l}$ or $<12 \mathrm{ng} / \mathrm{ml}$ represent the severest deficiency that inevitably results in osteomalacia, if untreated

- A growing number of researchers warn that the distinction between deficiency and insufficiency is artificial and there is much overlap between the two conditions.
- The cut-offs to define vitamin $\mathrm{D}$ deficiency should ideally be based on determining an optimal level for health as opposed to the minimum level to prevent severe deficiency

- It is hoped that the standardisation of operating procedures and reference intervals will improve with the production of a standard reference material by the National Institute of Standards and Technology (NIST), in collaboration with the National Institutes of Health's Office of Dietary Supplements.

- The prevalence of vitamin D deficiency is very well documented across the globe, and no age, race or the disease spectrum seem to be free of its presence.

- There is some evidence to support that vitamin D3 is more efficacious than vitamin D2 in raising and maintaining serum $25(\mathrm{OH})$ vitamin D levels

- There is no evidence of adverse effects with serum $25(\mathrm{OH}) \mathrm{D} \leq$ $70 \mathrm{ng} / \mathrm{ml}$, i.e. $175 \mathrm{nmol} / \mathrm{L}$. However, most trials have excluded subjects with renal insufficiency or hypercalcemia, and included short durations of exposure to vitamin D. Continuous monitoring is essential as the response to vitamin D supplementation or sun exposure widely varies.

- Varied results of calcium-vitamin D association for bone health have been reported, however, based on the current evidence, we recommend (at the very least in all post-menopausal women and men $>65$ years) the combination of minimum doses of $1200 \mathrm{mg}$ of calcium and $800 \mathrm{IU}$ of vitamin D for best therapeutic effect.

\section{References}

1. Holick MF (2003) Vitamin D: A millennium perspective. J Cell Biochem 88: 296307.

2. Brown AJ, Dusso A, Slatopolsky E (1999) Vitamin D. Am J Physiol 277: F157F175.

3. Norman AW, Nemere I, Zhou LX, Bishop JE, Lowe KE, et al. (1992) 1,25(OH)2vitamin D3, a steroid hormone that produces biologic effects via both genomic and nongenomic pathways. J Steroid Biochem Mol Biol 41: 231-240.

4. Hausler MR, Myrtle JF, Norman AW (1968) The association of a metabolite of vitamin D3 with intestinal mucosa chromatin in vivo. J Biol Chem 243: 40554064 .

5. Norman AW, Bishop JE, Bula CM, Olivera CJ, Mizwicki MT, et al. Molecular tools for study of genomic and rapid signal transduction responses initiated by 1 alpha,25(OH)(2)-vitamin D(3). Steroids 67: 457-466.

6. Holick MF (1995) Noncalcemic actions of 1,25-dihydroxyvitamin D3 and clinica applications. Bone 17: 107S-111S.

7. Huhtakangas JA, Olivera CJ, Bishop JE, Zanello LP, Norman AW (2004) The vitamin $\mathrm{D}$ receptor is present in caveolae-enriched plasma membranes and binds 1 alpha,25(OH)2-vitamin D3 in vivo and in vitro. Mol Endocrinol 18: 2660 2671.

8. Veldman CM, Cantorna MT, DeLuca HF (2000) Expression of 1,25-dihydroxyvitamin $D(3)$ receptor in the immune system. Arch Biochem Biophys 374: 334338

9. Holick MF (1995) Vitamin D: Photobiology, metabolism, and clinical applications. In Endocrinology ( $3^{\text {rd }}$ ed.). DeGroot, L., et al., Eds. Philadelphia: Saunders 990-1013.

10. Holick MF Vitamin D: photobiology, metabolism, mechanism of action, and clinical applications. In: Favus MJ, editor. Primer on the metabolic bone diseases and disorders of mineral metabolism. 4th ed. Philadelphia: Lippincott Williams \& Wilkins, 1999: 92-98.

11. Danish Institute for Food and Veterinary Research (2004) Vitamin D status in the Danish population should be improved. In Danish with English summary.

12. Holick MF (1998) Vitamin D requirements for humans of all ages: new increased requirements for women and men 50 years and older. Osteoporos Int 8: S24-S29. 
Citation: Haroon M, Fitzgerald O (2012) Vitamin D Deficiency and its Repletion: A Review of Current Knowledge and Consensus Recommendations. J Arthritis 1:105. doi:10.4172/2167-7921.1000105

13. Committee of Revision (1997) Drug information for the health care professional. Rockville, MD: United States Pharmacopeial Convention Inc.

14. Institute of Medicine (1997) Standing Committee on the Scientific Evaluation of Dietary Reference Intakes. Vitamin D. Dietary reference intakes: calcium, phosphorus, magnesium, vitamin D, and fluoride. Washington, DC: National Academy Press, 250-287.

15. Medicines Commission British Pharmacopoeia (1980) London, United Kingdom: Her Majesty's Stationery Office.

16. Houghton LA, Vieth $R$ (2006) The case against ergocalciferol (vitamin D2) as a vitamin supplement. Am J Clin Nutr 84: 694-697.

17. Cranney A, Horsley T, O'Donnell S, Weiler H, Puil L, et al. (2007) Effectiveness and safety of vitamin $D$ in relation to bone health. Evid Rep Technol Assess 158: 1-235.

18. Keane EM, Healy M, O'Moore R, Coakley D, Walsh JB (1998) Vitamin D-fortified liquid milk: benefits for the elderly community-based population. Calcif Tissue Int 62: 300-302.

19. Tangpricha V, Koutkia P, Rieke SM, Chen TC, Perez AA, et al. (2003) Fortification of orange juice with vitamin $D$ : a novel approach for enhancing vitamin $D$ nutritional health. Am J Clin Nutr 77: 1478-1483.

20. Natri AM, Salo P, Vikstedt T, Palssa A, Huttunen M, et al. (2006) Bread fortified with cholecalciferol increases the serum 25-hydroxyvitamin D concentration in women as effectively as a cholecalciferol supplement. J Nutr 136: 123-127.

21. de Jong N, Chin A Paw MJ, de Groot LC, de Graaf C, Kok FJ, et al. (1999) Functional biochemical and nutrient indices in frail elderly people are partly affected by dietary supplements but not by exercise. J Nutr 129: 2028-2036.

22. Chee WS, Suriah AR, Chan SP, Zaitun Y, Chan YM (2003) The effect of milk supplementation on bone mineral density in postmenopausal Chinese women in Malaysia. Osteoporos Int 14: 828-834.

23. Lau EM, Woo J, Lam V, Hong A (2001) Milk supplementation of the diet of postmenopausal Chinese women on a low calcium intake retards bone loss. $J$ Bone Miner Res 16: 1704-1709.

24. Palacios S, Castelo-Branco C, Cifuentes I, von Helde S, Baró L, et al. (2005) Changes in bone turnover markers after calcium-enriched milk supplementation in healthy postmenopausal women: a randomized, double-blind, prospective clinical trial. Menopause 12: 63-68.

25. Johnson JL, Mistry VV, Vukovich MD, Hogie-Lorenzen T, Hollis BW, et al. (2005) Bioavailability of vitamin D from fortified process cheese and effects on vitamin D status in the elderly. J Dairy Sci 88: 2295-2301.

26. Holick M (2003) Vitamin D: photobiology, metabolism, mechansim of action, and clinical applications. 5th ed. Washington DC: Humana Press.

27. LeBoff MS, Kohlmeier L, Hurwitz S, Franklin J, Wright J, et al. (1999) Occult vitamin $D$ deficiency in postmenopausal US women with acute hip fracture. JAMA 281: 1505-1511.

28. Scharla SH, Wolf S, Dull R, Lempert UG (1999) Prevalence of low bone mass and endocrine disorders in hip fracture patients in Southern Germany. Exp Clin Endocrinol Diabetes 107: 547-554.

29. Gloth FM 3rd, Gundberg CM, Hollis BW, Haddad JG Jr, Tobin JD (1995) Vitamin D deficiency in homebound elderly persons. JAMA 274: 1683-1686.

30. Gaugris S, Heaney RP, Boonen S, Kurth H, Bentkover JD, et al. (2005) Vitamin $\mathrm{D}$ inadequacy among post-menopausal women: a systematic review. QJM 98: 667-676.

31. Grant WB, Holick MF (2005) Benefits and requirements of vitamin D for optimal health: A review. Altern Med Rev 10(2): 94-111.

32. Holick MF (2004) Sunlight and vitamin D for bone health and prevention of autoimmune diseases, cancers, and cardiovascular disease. Am J Clin Nutr 80: 1678S-1688S

33. Holick MF (2002) Vitamin D: the underappreciated D-lightful hormone that is important for skeletal and cellular health. Curr Opin Endocrinol Diabetes 9 : 87-98.

34. Holick MF (2002) Sunlight and vitamin D: both good for cardiovascular health J Gen Intern Med 17: 733-735.

35. Webb RA (2006) Who, what, where and when - influences on cutaneous vitamin D synthesis. Progress in Biophysics and Molecular Biology 92: 17-25.
36. Diamond TH, Eisman JA, Mason RS. et al. (2005) Vitamin D and adult bone health in Australia and New Zealand: A position statement. Med J Aust 182 281-285.

37. Lo CW, Paris PW, Holick MF (1986) Indian and Pakistani immigrants have the same capacity as Caucasians to produce vitamin D in response to ultraviolet irradiation. Am J Clin Nutr 44: 683-685.

38. Samanek AJ, Croager EJ, Gies P, Milne E, Prince R, et al. (2006) Skin Cancer Prevention. Estimates of beneficial and harmful sun exposure times during the year for major Australian population centres. Med J Aust 184: 338-341.

39. Harris SS, Dawson-Hughes B (1998) Seasonal changes in plasma 25-hydroxyvitamin $D$ concentrations of young American black and white women. Am J Clin Nutr 67: 1232-1236.

40. Webb AR, Kline L, Holick MF (1988) Influence of season and latitude on the cutaneous synthesis of vitamin D3: exposure to winter sunlight in Boston and Edmonton will not promote vitamin D3 synthesis in human skin. J Clin Endocrinol Metab 67: 373-378.

41. Chel VG, Ooms ME, Popp-Snijders C, Pavel S, Schothorst AA, et al. (1998) Ultraviolet irradiation corrects vitamin $D$ deficiency and suppresses secondary hyperparathyroidism in the elderly. J Bone Miner Res 13: 1238-1242.

42. Lovell GA, Byth JL, Craswell PW, et al. (1988) The influence of sunlight or dietary vitamin $\mathrm{D}$ on plasma 25 -hydroxyvitamin $\mathrm{D}$ in institutionalized elderly patients in a sub-tropical climate. J Hum Nutr Diet 1: 163-170.

43. Marks R, Foley PA, Jolley D, Knight KR, Harrison J, et al. (1995) The Effect of Regular Sunscreen Use on Vitamin D Levels in an Australian Population. Arch Dermatol 131: 415-421.

44. Matsuoka LY, Wortsman J, Haddad JG, Hollis BW (1992) Elevation of blood vitamin D2 levels does not impede the release of vitamin D3 from the skin. Metabolism 41: 1257-1260

45. Reid IR, Gallagher DJ, Bosworth J (1986) Prophylaxis against vitamin D deficiency in the elderly by regular sunlight exposure. Age Ageing 15: 35-40.

46. Ho ML, Yen HC, Tsang RC, Specker BL, Chen XC, et al. (1985) Randomized study of sunshine exposure and serum 25-OHD in breast-fed infants in Beijing, China. J Pediatr 107: 928-931.

47. Toss G, Andersson R, Diffey BL, Fall PA, Larkö O, et al. (1982) Oral vitamin D and ultraviolet radiation for the prevention of vitamin $\mathrm{D}$ deficiency in the elderly. Acta Paediatr Scand 212: 157-161.

48. Falkenbach A, Unkelbach U, Boehm BO, Regeniter A, Stein J, et al. (1993) Bone metabolism before and after irradiation with ultraviolet light. Eur J App Physiol 66: 55-59.

49. Matsuoka LY, Ide L, Wortsman J, MacLaughlin JA, Holick MF (1987) Sunscreens suppress cutaneous vitamin D3 synthesis. J Clin Endocrinol Metab 64: $1165-1168$.

50. Matsuoka LY, Wortsman J, Hanifan N, Holick MF (1988) Chronic sunscreen use decreases circulating concentrations of 25 -hydroxyvitamin D. A preliminary study. Arch Dermatol 124: 1802-1804

51. Matsuoka LY, Wortsman J, Hollis BW (1990) Use of topical sunscreen for the evaluation of regional synthesis of vitamin D3. J Am Acad Dermatol 22: 772 775

52. Farrerons J, Barnadas M, Rodriguez J, Renau A, Yoldi B, et al. (1998) Clinically prescribed sunscreen (sun protection factor 15 ) does not decrease serum vitamin $\mathrm{D}$ concentration sufficiently either to induce changes in parathyroid function or in metabolic markers. Br J Dermatol 139: 422-427.

53. Farrerons J, Barnadas M, Lopez-Navidad A, Renau A, Rodríguez J, et al. (2001) Sunscreen and risk of osteoporosis in the elderly: a two-year follow-up. Dermatology 202: 27-30

54. Harris SS, Dawson-Hughes B (2007) Reduced sun exposure does not explain the inverse association of 25-hydroxyvitamin $D$ with percent body fat in older adults. J Clin Endocrin Metab 92: 3155-3157.

55. Kligman EW, Watkins A, Johnson K, Kronland R (1989) The impact of lifestyle factors on serum 25-hydroxy vitamin $D$ levels in older adults: a preliminary study. Fam Pract Res J 9: 11-19.

56. Kimlin M, Harrison S, Nowak M, Moore M, Brodie A, et al. (2007) Does a high UV environment ensure adequate vitamin D status? J Photochem Photobiol B 89: 139-147. 
Citation: Haroon M, Fitzgerald O (2012) Vitamin D Deficiency and its Repletion: A Review of Current Knowledge and Consensus Recommendations. J Arthritis 1:105. doi:10.4172/2167-7921.1000105

57. Norval M, Wulf HC (2009) Does chronic sunscreen use reduce vitamin D production to insufficient levels? Br J Dermatol 161: 732-736.

58. Kennedy C, Bajdik CD, Willemze R, de Gruijl FR, Bavinck JN (2003) The influence of painful sunburns and lifetime of sun exposure on the risk of actinic keratoses, seborrheic warts, melanocytic nevi, atypical nevi and skin cancer. J Invest Dermatol 120: 1087-1093.

59. Information Services Division (2012) ISD Scotland is part of NHS National Services Scotland.

60. Moan J, Porojnicu AC, Dahlback A, Setlow RB (2008) Addressing the health benefits and risks, involving vitamin $D$ or skin cancer, of increased sun exposure. Proc Natl Acad Sci 105: 668-673.

61. Grant WB, Garland CF (2006) The association of solar ultraviolet B (UVB) with reducing risk of cancer: multifactorial ecologic analysis of geographic variation in age-adjusted cancer mortality rates. Anticancer Res 26: 2687-2699.

62. Picciano MF (2001) Nutrient composition of human milk. Pediatr Clin North Am 48: 53-67.

63. Wagner CL, Greer FR, Section on Breastfeeding and Committee on Nutrition (2008) American Academy of Pediatrics Section on Breastfeeding; American Academy of Pediatrics Committee on Nutrition. Prevention of rickets and vitamin D deficiency in infants, children, and adolescents. Pediatrics 122: 1142 1152.

64. Javaid MK, Crozier SR, Harvey NC, Gale CR, Dennison EM, et al. (2006) Maternal vitamin $\mathrm{D}$ status during pregnancy and childhood bone mass at age 9 years: a longitudinal study. Lancet 367: 36-43.

65. Camargo CA Jr, Rifas-Shiman SL, Litonjua AA, Rich-Edwards JW, Weiss ST, et al. (2007) Maternal intake of vitamin D during pregnancy and risk of recurrent wheeze at 3 y of age. Am J Clin Nutr 85: 788-795

66. Ward LM, Gaboury I, Ladhani M, Zlotkin S (2007) Vitamin D-deficiency rickets among children in Canada. CMAJ 177: 161-166.

67. Scotti A, Bianchini C, Gianalfredo A, Marzo A (2001) Absorption of calcium administered alone or in fixed combination with vitamin $D$ to healthy volunteers. Arzneimittelforschung 51: 493-500.

68. Heaney RP, Dowell MS, Hale CA, Bendich A (2003) Calcium absorption varies within the reference range for serum 25 -hydroxyvitamin D. J Am Coll Nutr 22: 142-146.

69. Barger-Lux MJ, Heaney RP (2002) Effects of above average summer sun exposure on serum 25-hydroxyvitamin $\mathrm{D}$ and calcium absorption fraction. $\mathrm{J}$ Clin Endocrinol Metab 87: 4952-4956.

70. Mosekilde L(2005) Vitamin D and the elderly. Clin Endocrinol (Oxf) 62: 265-281.

71. Bischoff-Ferrari HA, Giovannucci E, Willett WC, Dietrich T, Dawson-Hughes B (2006) Estimation of optimal serum concentrations of 25-hydroxyvitamin D for multiple health outcomes. Am J Clin Nutr 84: 18-28.

72. Holick MF (2007) Vitamin D deficiency. N Engl J Med 357: 266-281.

73. Hollis BW, Wagner CL (2006) Vitamin D deficiency during pregnancy: an ongoing epidemic. Am J Clin Nutr 84: 272.

74. Vieth R (1999) Vitamin D supplementation, 25-hydroxyvitamin D concentrations and safety. Am J Clin Nutr. 69: 842-856.

75. Hollis BW, Horst RL (2007) The assessment of circulating 25(OH)D and $1,25(\mathrm{OH})_{2} \mathrm{D}$ : where we are and where we are going. J Steroid Biochem Mol Biol 103: 473-476.

76. Binkley N, Krueger D, Cowgill CS, Plum L, Lake E, et al. (2004) Assay variation confounds the diagnosis of hypovitaminosis D: a call for standardization. J Clin Endocrinol Metab 89: 3152-3157.

77. Hollis BW (2000) Comparison of commercially available 125I-based RIA methods for the determination of circulating 25-hydroxyvitamin D. Clin Chem 46: 1657-1661.

78. Institute of Medicine, Food and Nutrition Board (2011) Dietary Reference Intakes for Calcium and Vitamin D. Washington, DC: National Academy Press.

79. NIST Tech beat (2009) NIST Releases Vitamin D Standard Reference Material.

80. Haroon M, Bond U, Quillinan N, Phelan MJ, Regan MJ (2011) The prevalence of vitamin $\mathrm{D}$ deficiency in consecutive new patients seen over a 6 -month period in general rheumatology clinics. Clin Rheumatol 30: 789-794.
81. Mouyis M, Ostor AJ, Crisp AJ, Ginawi A, Halsall DJ, et al. (2008) Hypovitaminosis $\mathrm{D}$ among rheumatology outpatients in clinical practice. Rheumatology (Oxford) 47: 1348-1351.

82. Rovner AJ, Stallings VA, Schall JI, Leonard MB, Zemel BS (2007) Vitamin D insufficiency in children, adolescents, and young adults with cystic fibrosis despite routine oral supplementation. Am J Clin Nutr 86: 1694-1699.

83. Aris RM, Merkel PA, Bachrach LK, Borowitz DS, Boyle MP, et al. (2005) Guide to bone health and disease in cystic fibrosis. J Clin Endocrinol Metab 90: 1888 $-1896$.

84. Borowitz D, Baker RD, Stallings V (2002) Consensus report on nutrition for pediatric patients with cystic fibrosis. J Pediatr Gastroenterol Nutr 35: 246 -259.

85. Prentice A (2008) Vitamin D deficiency: a global perspective. Nutr Rev 66 S153-S164.

86. Schroth RJ, Lavelle CLB, Moffatt MEK (2005) A review of vitamin D deficiency during pregnancy: who is affected? Int J Circumpolar Hlth 64: 112-120.

87. Bener A, Al-Ali M, Hoffmann GF (2009) Vitamin D deficiency in healthy children in a sunny country: associated factors. Int J Food Sci Nutr 60: 60-70.

88. Bener A, Al-Ali M, Hoffmann GF (2009) High prevalence of vitamin D deficiency in young children in a highly sunny humid country: a global health problem. Minerva Pediatr 61: 15-22.

89. Mansoor S, Habib A, Ghani F, Fatmi Z, Badruddin S, et al. (2010) Prevalence and significance of vitamin $D$ deficiency and insufficiency among apparently healthy adults. Clin Biochem 43: 1431-1435.

90. Dagnelie PC, Vergote FJ, van Staveren WA, van den Berg H, Dingian PG, et al. (1990) High prevalence of rickets in infants on macrobiotic diets. Am J Clin Nutr 51: 202-208.

91. Odeka E, Tan J (2005) Nutritional rickets is increasingly diagnosed in children of ethnic origin. Arch Dis Chld 90: 1203-1204.

92. Allgrove J (2004) Is nutritional rickets returning? Arch Dis Chld 89: 699-701.

93. Shaw NJ, Pal BR (2002) Vitamin D deficiency in UK Asian families: activating a new concern. Arch Dis Chld 86: 147-149.

94. Shenoy SD, Swift P, Cody D, Iqbal J (2005) Maternal vitamin D deficiency, refractory neonatal hypocalcaemia, and nutritional rickets. Arch Dis Chld 90: 437-438.

95. Pedersen P, Michaelsen KF, Mølgaard C (2003) Children with nutritional rickets referred to hospitals in Copenhagen during a 10-year period. Acta Paediatr 92: 87-90.

96. Robinson PD, Högler W, Craig ME, et al. (2006) The re-emerging burden of rickets: a decade of experience from Sydney. Arch Dis Chld 91: 564-568.

97. Judkins A, Eagleton C (2006) Vitamin D deficiency in pregnant New Zealand women. N Z Med J 119: U2144.

98. Bruyère $O$, Malaise $O$, Neuprez $A$, Collette J, Reginster JY (2007) Prevalence of vitamin $D$ inadequacy in European postmenopausal women. Curr Med Res Opin 23: 1939-1944.

99. Dao CN, Patel P, Overton ET, Rhame F, Pals SL, et al. (2011) Low Vitamin D among HIV-Infected Adults: Prevalence of and Risk Factors for Low Vitamin D Levels in a Cohort of HIV-Infected Adults and Comparison to Prevalence among Adults in the US General Population. Clin Infect Dis 52: 396-405.

100. Lee P, Eisman JA, Center JR (2009) Vitamin D deficiency in critically ill patients. N Engl J Med 360: 1912-1914.

101. Gloth FM, Gundberg CM, Hollis BW, Haddad HG, Tobin JD (1995) Vitamin D deficiency in homebound elderly persons. JAMA 274: 1683-1686.

102. Malabanan A, Veronikis IE, Holick MF (1998) Redefining vitamin D insufficiency. Lancet 351: 805-806.

103. Tangpricha V, Pearce EN, Chen TC, Holick MF (2002) Vitamin D insufficiency among free-living healthy young adults. Am J Med 112: 659-662.

104. Ryan P, Dixon T (2006) Prevalence of vitamin D inadequacy in patients attending a metabolic bone clinic in Medway. Curr Med Res Opin 22: 211-216.

105. Chatfield SM, Brand C, Ebeling PR, Russell DM (2007) Vitamin D deficiency in general medical inpatients in summer and winter. Intern Med J 37: 377-382.

106. Dixon T, Mitchell P, Beringer T, Gallacher S, Moniz C, et al. (2006) An over- 
Citation: Haroon M, Fitzgerald O (2012) Vitamin D Deficiency and its Repletion: A Review of Current Knowledge and Consensus Recommendations. J Arthritis 1:105. doi:10.4172/2167-7921.1000105

view of the prevalence of 25-hydroxy-vitamin D inadequacy amongst elderly patients with or without fragility fracture in the United Kingdom. Curr Med Res Opin 22: 405-415.

107. Knutsen KV, Brekke M, Gjelstad S, Lagerløv P (2010) Vitamin D status in patients with musculoskeletal pain, fatigue and headache: a cross-sectional descriptive study in a multi-ethnic general practice in Norway. Scand J Prim Health Care 28: 166-171.

108. Hess AF, Lewis JM, Rivkin H (1930) Newer aspects of the therapeutics of viosterol (irradiated ergosterol). JAMA 94: 1885-1889.

109. Holmberg I, Berlin T, Ewerth S, Bjorkhem I (1986) 25-Hydroxylase activity in subcellular fractions from human liver. Evidence for different rates of mitochondrial hydroxylation of vitamin D2 and D3. Scand J Clin Lab Invest 46 : 785-790.

110. Horst RL, Prapong S, Reinhardt TA, Koszewski NJ, Knutson J, et al. (2000) Comparison of the relative effects of 1,24-dihydroxyvitamin $\mathrm{D}_{2}\left[1,24-(\mathrm{OH})_{2} \mathrm{D}_{2}\right]$, 1,24-dihydroxyvitamin $\mathrm{D}_{3}\left[1,24-(\mathrm{OH})_{2} \mathrm{D}_{3}\right]$, and 1,25-dihydroxyvitamin $\mathrm{D}_{3}$ $\left[1,25-(\mathrm{OH})_{2} \mathrm{D}_{3}\right]$ on selected vitamin D-regulated events in the rat. Biochem Pharmacol 60: 701-708

111. Hoy DA, Ramberg CF, Horst RL (1988) Evidence that discrimination agains ergocalciferol by the chick is the result of enhanced metabolic clearance rates for its mono- and dihydroxylated metabolites. J Nutr 118: 633-638.

112. Marx SJ, Jones G, Weinstein RS, Chrousos GP, Renquist DM (1989) Differences in mineral metabolism among nonhuman primates receiving diets with only vitamin D3 or only vitamin D2. J Clin Endocrinol Metab 69: 1282-1289.

113. Horst RL, Napoli JL, Littledike ET (1982) Discrimination in the metabolism of orally dosed ergocalciferol and cholecalciferol by the pig, rat and chick. Biochem J 204: 185-189.

114. Trang H, Cole DE, Rubin LA, Pierratos A, Siu S, et al. (1998) Evidence that vitamin D3 increases serum 25-hydroxyvitamin D more efficiently than does vitamin D2. Am J Clin Nutr 68: 854-848.

115. Mastaglia SR, Mautalen CA, Parisi MS, Oliveri B (2006) Vitamin D2 dose required to rapidly increase $25 \mathrm{OHD}$ levels in osteoporotic women. Eur $\mathrm{J}$ Clin Nutr 60: 681-687

116. Armas LA, Hollis BW, Heaney RP (2004) Vitamin D2 is much less effective than vitamin D3 in humans. J Clin Endocrinol Metab 89: 5387-5391.

117. Vieth R, Ladak Y, Walfish PG (2003) Age-related changes in the 25-hydroxyvitamin $\mathrm{D}$ versus parathyroid hormone relationship suggest a different reason why older adults require more vitamin D. J Clin Endocrinol Metab 88: 185-191.

118. Cooper L, Clifton-Bligh PB, Nery ML, Figtree G, Twigg S, et al. (2003) Vitamin $\mathrm{D}$ supplementation and bone mineral density in early postmenopausal women. Am J Clin Nutr 77: 1324-1329.

119. Heaney RP, Recker RR, Grote J, Horst RL, Armas LA (2011) Vitamin D(3) is more potent than vitamin $\mathrm{D}(2)$ in humans. J Clin Endocrinol Metab 96: E447E452.

120. Holick MF, Biancuzzo RM, Chen TC, Klein EK, Young A, et al. (2008) Vitamin D2 is as effective as vitamin D3 in maintaining circulating concentrations of 25-hydroxyvitamin D. J Clin Endocrinol Metab 93: 677-681.

121. Markestad T, Aksnes L, Ulstein M, Aarskog D (1984) 25-Hydroxyvitamin D and 1,25-dihydroxyvitamin D of D2 and D3 origin in maternal and umbilical cord serum after vitamin D2 supplementation in human pregnancy. Am J Clin Nutr 40: 1057-1063.

122. Rapuri PB, Gallagher JC, Haynatzki G (2004) Effect of vitamins D2 and D3 supplement use on serum $25 \mathrm{OHD}$ concentration in elderly women in summer and winter. Calcif Tissue Int 74: 150-156.

123. Lips P, Duong T, Oleksik A, Black D, Cummings S, et al. (2001) A global study of vitamin $D$ status and parathyroid function in postmenopausal women with osteoporosis: baseline data from the multiple outcomes of raloxifene evaluation clinical trial. J Clin Endocrinol Metab 86: 1212-1221.

124. Terrence H Diamond, John A Eisman, Rebecca S Mason, Caryl A Nowson, Julie A Pasco, et al. (2005) Vitamin D and adult bone health in Australia and New Zealand: a position statement. Med J Aust 182: 281-285.

125. Grassroots Health. A Public Health Promotion Organisation.

126. Canadian Cancer Society (2007) Canadian Cancer Society Announces Vitamin D Recommendation.
127. Marcinowska-Suchowierska E, Walicka M, Tałałaj M, Horst-Sikorska W, Ignaszak-Szczepaniak M, et al. (2010) Vitamin D supplementation in adults guidelines. Endokrynol Pol 61: 723-729.

128. Dawson-Hughes B, Heaney RP, Holick MF, Lips P, Meunier PJ, et al. (2005) Estimates of optimal vitamin D status. Osteoporos Int 16: 713-716.

129. Dawson-Hughes B, Mithal A, Bonjour JP, Boonen S, Burckhardt P, et al. (2010) IOF position statement: vitamin D recommendations for older adults. Osteoporos Int 21: 1151-1154

130. Hanley DA, Cranney A, Jones G, Whiting SJ, Leslie WD, et al. (2010) Vitamin $D$ in adult health and disease: a review and guideline statement from Osteoporosis Canada. CMAJ 182: E610-E618.

131.Papaioannou A, Morin S, Cheung AM, Atkinson S, Brown JP, et al. (2010) 2010 clinical practice guidelines for the diagnosis and management of osteoporosis in Canada: summary. CMAJ 182: 1864-1873.

132. Heaney RP, Holick MF (2011) Why the IOM recommendations for vitamin D are deficient. J Bone Miner Res 26: 455-457.

133. Sanders KM, Stuart AL, Williamson EJ, Simpson JA, Kotowicz MA, et al. (2010) Annual high-dose oral vitamin D and falls and fractures in older women: a randomized controlled trial. JAMA 303: 1815-1822.

134. Smith H, Anderson F, Raphael H, Maslin P, Crozier S, et al. (2007) Effect of annual intramuscular vitamin $\mathrm{D}$ on fracture risk in elderly men and women--a population-based, randomized, double-blind, placebo-controlled trial. Rheumatology (Oxford) 46: 1852-1857.

135. Chapuy MC, Arlot ME, Duboeuf F, Brun J, Crouzet B, et al. (1992) Vitamin D3 and calcium to prevent hip fractures in elderly women. N Engl J Med 327 $1637-1642$

136. Porthouse J, Cockayne S, King C, Saxon L, Steele E, et al. (2005) Randomized controlled trial of calcium and supplementation with cholecalciferol (vitamin D3) for prevention of fractures in primary care. BMJ 330: 1003-1006.

137. Brant AM, Avenell A, Campbell MK, McDonald AM, Maclenan GS, McPherosn GC et al (2005) Oral vitamin D3 and calcium for secondary prevention of low- trauma fractures in elderly people (Randomized Evaluation of Calcium Or Vitamin D, RECORD) a randomized placebo-controlled trial. Lancet 365 $1621-1628$

138. Jackson RD, LaCroix AZ, Gass M, Wallace RB, Robbins J, et al. (2006) Calcium plus vitamin $\mathrm{D}$ supplementation and the risk of fractures. $\mathrm{N}$ Engl $\mathrm{J}$ Med 354: 669-683.

139. Heaney RP, Barger-Lux MJ, Dowell MS, Chen TC, Holick MF (1997) Calcium absorptive effects of vitamin D and its major metabolites. J Clin Endocrino Metab 82: 4111-4116.

140. Steingrimsdottir L, Gunnarsson O, Indridason OS, Franzson L, Sigurdsson $\mathrm{G}$ (2005) Relationship between serum parathyroid hormone levels, vitamin D sufficiency, and calcium intake. JAMA 294, 2336-2341.

141. Bischoff-Ferrari HA, Dawson-Hughes B, Baron JA, Burckhardt P, Li R, et al. (2007) Calcium intake and hip fracture risk in men and women: a meta-analysis of prospective cohort studies and randomized controlled trials. Am J Clin Nutr 86: 1780-1790.

142. Bischoff-Ferrari HA, Willett WC, Wong JB, Stuck AE, Staehelin HB, et al. (2009) Prevention of nonvertebral fractures with oral vitamin D and dose dependency: a meta-analysis of randomized controlled trials. Arch Intern Med 169: 551-561.

143. Tang BM, Eslick GD, Nowson C, Smith C, Bensoussan A (2007) Use of calcium or calcium in combination with vitamin $D$ supplementation to prevent fractures and bone loss in people aged 50 years and older: a meta-analysis. Lancet 370: 657-666.

144. The DIPART (vitamin D Individual Patient Analysis of Randomized Trials) Group (2010) Patient level pooled analysis of 68500 patients from seven major vitamin D fracture trials in US and Europe. BMJ 340: b5463.

145. Boonen S, Lips P, Bouillon R, Bischoff-Ferrari HA, Vanderschueren D, et al (2007) Need for additional calcium to reduce the risk of hip fracture with vitamin D supplementation: evidence from a comparative meta-analysis of randomized controlled trials. J Clin Endocrinol Metab 92: 1415-1423.

146. Avenell A, Gillespie WJ, Gillespie LD, O'Connell D (2009) Vitamin D and vitamin $D$ analogues for preventing fractures associated with involutional and post-menopausal osteoporosis. Cochrane Database Syst Rev 3: CD000227. 
Citation: Haroon M, Fitzgerald O (2012) Vitamin D Deficiency and its Repletion: A Review of Current Knowledge and Consensus Recommendations. J Arthritis 1:105. doi:10.4172/2167-7921.1000105

147. Rizzoli R, Boonen S, Brandi ML, Burlet N, Delmas P, et al. (2008) The role of calcium and vitamin $D$ in the management of osteoporosis. Bone 42: 246-249.

148. Bolland MJ, Avenell A, Baron JA, Grey A, MacLennan GS, et al. (2010) Effect of calcium supplements on risk of myocardial infarction and cardiovascular events: meta-analysis. BMJ 341: c3691.

149. Bolland MJ, Barber PA, Doughty RN, Mason B, Horne A, et al. (2008) Vascular events in healthy older women receiving calcium supplementation: randomised controlled trial. BMJ 336: 262-266.

150. Lewis JR, Calver J, Zhu K, Flicker L, Prince RL (2011) Calcium supplementation and the risks of atherosclerotic vascular disease in older women: results of a 5-year RCT and a 4.5-year follow-up. J Bone Miner Res 26: 35-41.

151. Avenell A, MacLennan GS, Jenkinson DJ, McPherson GC, McDonald AM, et al. Long-term follow-up for mortality and cancer in a randomized placebo-controlled trial of vitamin $\mathrm{D}(3)$ and/or calcium (RECORD trial). J Clin Endocrinol Metab 97: 614-22.

152. Hsia J, Heiss G, Ren H, Allison M, Dolan NC, et al. Women's health initiative investigators Calcium/vitamin D supplementation and cardiovascular events. Circulation 115: 846-854.
153. Vieth R (1999) Vitamin D supplementation, 25-hydroxyvitamin D concentration, and safety. Am J Clin Nutr 69: 842-856.

154. Heaney RP, Davies KM, Chen TC, Holick MF, Barger-Lux MJ (2003) Human serum 25 hydroxycholecalciferol response to extended oral dosing with cholecalciferol. Am J Clin Nutr 77: 204-210.

155. Vieth $R$ (2004) Why the optimal requirement for vitamin D3 is probably much higher than what is officially recommended for adults. J Steroid Biochem Mol Biol 89-90: 575-579.

156. Vieth R, Chan PC, MacFarlane GD (2001) Efficacy and safety of vitamin D3 intake exceeding the lowest observed adverse effect level. Am J Clin Nutr 73: 288-294.

157. Blank S, Scanlon KS, Sinks TH, Lett S, Falk H (1995) An outbreak of hypervitaminosis $D$ associated with the overfortification of milk from a home-delivery dairy. Am J Public Health 85: 656-659.

158. Vieth R (1999) Vitamin D supplementation, 25-hydroxyvitamin D concentrations, and safety. Am J Clin Nutr 69: 842-856.

159. Hewison M, Burke F, Evans KN, Lammas DA, Sansom DM, et al. (2007) Extrarenal 25-hydroxyvitamin D3-1alpha-hydroxylase in human health and disease. J Steroid Biochem Mol Biol 103: 316-321. 